JURNAL RISET PENDIDIKAN MATEMATIKA

Volume 3 - Nomor 1, Mei 2016, (66 - 75)

Available online at http://journal.uny.ac.id/index.php/jrpm

\title{
PENGEMBANGAN PERANGKAT PEMBELAJARAN VEKTOR DENGAN PENDEKATAN CREATIVE PROBLEM SOLVING KELAS XI SMK TEKNOKESTAN
}

\author{
Muh. Fajaruddin Atsnan \\ Jurusan Pendidikan Matematika, STKIP PGRI Banjarmasin, Jalan Sultan Adam Kompleks Haji Iyus \\ No. 18, Banjarmasin, Kalimantan Selatan, 70121, Indonesia \\ Korespondensi Penulis. Email: ats_krnbangettt@yahoo.co.id, Telp: +6287839494083 \\ Received: 15 ${ }^{\text {th }}$ August 2016; Revised: $20^{\text {th }}$ August 2016; Accepted: $7^{\text {th }}$ September 2016
}

\begin{abstract}
Abstrak
Penelitian ini bertujuan untuk menghasilkan perangkat pembelajaran vektor dengan pendekatan Creative Problem Solving untuk kelas XI SMK Teknokestan, meliputi rencana pelaksanaan pembelajaran (RPP) dan lembar kegiatan siswa (LKS) yang valid, praktis, dan efektif, serta tes prestasi belajar siswa (TPB) yang valid dan praktis. Jenis penelitian ini adalah penelitian pengembangan (research \& development). Penelitian ini menggunakan model pengembangan 4D yang terdiri atas empat tahap pengembangan yaitu define, design, development, dan disseminate. Aspek kevalidan produk -dilihat dari hasil validasi ahli yang mencapai kriteria sangat valid. Aspek kepraktisan produk -dilihat dari hasil pengisian lembar kepraktisan oleh guru yang mencapai kriteria sangat praktis, hasil pengisian lembar kepraktisan oleh siswa yang mencapai kriteria baik, dan lembar observasi keterlaksanaan pembelajaran menunjukkan bahwa persentase minimal keterlaksanaan pembelajaran adalah $83,3 \%$ dan maksimal adalah $86,1 \%$. Aspek keefektifan dilihat dari hasil tes prestasi belajar siswa mencapai nilai KKM setiap kelas lebih dari $70 \%$.
\end{abstract}

Kata kunci: pengembangan, perangkat pembelajaran, Creative Problem Solving

\section{DEVELOPING LEARNING KIT ON MATERIAL VECTOR WITH CREATIVE PROBLEM SOLVING APPROACH GRADE XI SMK TEKNOKESTAN}

\begin{abstract}
This reseach was aimed to develop learning kit of vector with Creative Problem Solving approach in grade XI -SMK Teknokestan, covering lesson plan and worksheet which is valid, practical, and effective, -and learning achievement test which is valid and practical. The research is research \& development, which was carried out by the implementation of $4 D$ development model, which consist of four stages: define, design, development, and dissemination. The product validity can be seen from the result of expert validation who claimed that the criteria of product was very valid. The product practicality can be seen from the result of the teacher practicality sheets which show that the product criteria was very good; the result of the student practicality sheets show that the product criteria was good; the learning implementation observation sheets show that the minimum implementation percentage was $83.3 \%$ and maximum was $86.1 \%$. The effective product can be seen from the result of learning achievement test reach KKM more than $70 \%$.
\end{abstract}

Keywords: development, learning kit, Creative Problem Solving

How to Cite: Atsnan, M. (2016). Pengembangan perangkat pembelajaran vektor dengan pendekatan creative problem solving kelas XI SMK Teknokestan. Jurnal Riset Pendidikan Matematika, 3(1), 66-75. doi:http://dx.doi.org/10.21831/jrpm.v3i1.10406

Permalink/DOI: http://dx.doi.org/10.21831/jrpm.v3i1.10406 


\section{PENDAHULUAN}

Kemajuan dan perkembangan zaman menuntut adanya perbaikan dan inovasi secara berkelanjutan dalam dunia pendidikan di Indonesia. Perbaikan dan inovasi yang dimaksud salah satunya berkaitan dengan proses pembelajaran. Permendiknas Nomor 19 Tahun 2005 tentang Standar Nasional Pendidikan menjelaskan bahwa proses pembelajaran pada satuan pendidikan harus dilaksanakan secara interaktif, inspiratif, menyenangkan, menantang, dan mampu untuk memotivasi siswa agar mampu berpartisipasi secara aktif. Makna yang terkandung dalam peraturan tersebut menunjukkan bahwa siswa harus terlibat secara aktif dan ikut berpartisipasi dalam proses pembelajaran, bukan hanya mendengarkan dan mencatat penjelasan dari guru, namunsiswa harus terlibat aktif dalam pembelajaran agar dapat mengembangkan berbagai macam potensi yang dimilikinya. Proses pembelajaran dengan siswa aktif mengkonstruksi suatu konsep dan guru sebagai fasilitator serta memberikan scaffolding ketika siswa mengalami kesulitan dapat mengembangkan kreativitas siswa.

Salah satu masalah yang dihadapi dunia pendidikan di Indonesia adalah masalah lemahnya proses pembelajaran. Metode konvensional dalam proses pembelajaran terjadi manakala guru mengajar dengan metode ceramah sedangkan siswa hanya datang, duduk, diam, mendengarkan, mencatat dan menghafal materi yang disampaikan guru. Suasana yang demikian tidak mendukung siswa untuk berpartisipasi penuh dalam pembelajaran. Seperti yang dinyatakan oleh Tileston $(2007$, p.4) "the environment in the classroom is collaborative and supportive". Suasana lingkungan pembelajaran dalam kelas sangat penting untuk mendukung siswa agar lebih bersemangat dalam proses pembelajaran. Guru harus bisa menciptakan suasana kelas yang menyenangkan dan mendukung siswa untuk terlibat secara aktif, sehingga mereka mempunyai semangat yang tinggi untuk belajar. Selain itu, guru harus dapat meyakinkan siswa akan manfaat dari materi yang dipelajari bagi kehidupan nyata mereka serta peran penting matematika dalam berbagai bidang.

Matematika memiliki peran penting dalam kehidupan. Demikian pentingnya, matematika dijuluki sebagai queen of sciences yang berarti ratunya para ilmu sekaligus pelayannya. Banyak ilmu yang penemuan dan pengembangannya bergantung pada matematika. Matematika memiliki peran yang penting bagi semua masyarakat modern untuk digunakan dalam berbagai bidang dan kebutuhan. Hal ini dapat dilihat dari penerapan matematika pada berbagai bidang kehidupan seperti ekonomi, perdagangan, teknologi, dan sebagainya. Matematika adalah dasar untuk kemakmuran nasional dalam menyediakan bahan/alat untuk pemahaman ilmu pengetahuan, teknik, teknologi, dan ekonomi (Gauhar, 2012, p.45). Matematika dapat dimaknai dan dipahami sebagai suatu disiplin ilmu yang runtut, terstruktur dan antara bagian yang satu dengan bagian lainnya terdapat saling keterkaitan. Berdasarkan kenyataan tersebut, terlihat bahwa matematika harus bisa dipahami oleh siswa karena memiliki peran yang penting dalam kehidupan.

Matematika merupakan ilmu mengenai pola-pola yang abstrak yang memiliki karakteristik sebagai alat untuk menyelesaikan masalah, sebagai pondasi kajian ilmiah dan teknologi, serta dapat memberikan cara-cara untuk memodelkan situasi dalam kehidupan nyata (Chambers, 2008: p.8). Matematika menekankan pada penyelesaian suatu masalah, dan masalah dalam matematika tersebut biasanya disajikan dalam bentuk soal matematika. Suatu pertanyaan akan merupakan suatu masalah hanya jika seseorang belum mempunyai aturan atau hukum tertentu yang segera dapat dipergunakan untuk menemukan jawaban dari pertanyaan tersebut.

Masalah merupakan sesuatu yang membutuhkan tindakan. Suatu masalah merupakan kesenjangan antara keadaan sekarang dengan tujuan yang ingin dicapai, sementara kita tidak mengetahui apa yang harus dikerjakan untuk mencapai tujuan tersebut. Masalah dapat diartikan sebagai pertanyaan yang harus dijawab pada saat itu, sedangkan kita tidak mempunyai rencana solusi yang jelas.

Masalah dibagi menjadi 3 tingkatan, yaitu simple problem, complicated problem, dan complex problem (Steiner, 2009, p.10). Simple problem mengandung maksud hanya memuat sedikit elemen yang relatif sedikit keterkaitannya, sehingga relatif mudah untuk diselesaikan. Complicated problem hampir sama dengan simple problem, hanya saja dalam complicated problem terdapat perbandingan dari tiap-tiap elemen, yang saling berkaitan. Simple problem dapat diselesaikan dengan cara atau metode standar, tetapi dalam complicated problem tidak demikian, harus menggunakan cara atau metode yang lebih sophisticated (canggih/rumit). Meskipun demikian, simple dan complicated problem 
dapat diselesaikan dengan metode atau cara penyelesaian sebagai hasil dari proses berpikir routine problem solving, tanpa memerlukan proses creative problem solving.

Suatu masalah dikatakan sebagai complex problem, jika tidak dapat diselesaikan berdasarkan proses routine problem solving, tetapi harus membuat koneksi/hubungan baru terhadap berbagai aspek/konsep yang terkait. Bagi orang yang mempunyai pengetahuan dan pengalaman cukup, dalam memandang suatu situasi tertentu akan berbeda dengan orang lain yang mempunyai pengetahuan dan pengalaman kurang/ berbeda. Salah satu cara untuk menyelesaikan complex problem yaitu melalui Creative Problem Solving (CPS). Sulistyowati \& Sugiman (2014) mengemukakan bahwa langkah-langkah dalam CPS dapat membantu menyelesaikan masalah sehingga dapat membantu siswa dalam mencapai prestasi belajar dan kemampuan penalaran matematis.

Aspek kreatif sangat dibutuhkan dalam pendekatan Creative Problem Solving (CPS) untuk mencari berbagai gagasan ide guna memilih solusi yang optimal dan terbaik. Sementara untuk memperoleh berbagai gagasan ide guna memilih solusi yang optimal dan terbaik, sangat dibutuhkan adanya kemampuan berpikir kritis. Hal ini sesuai dengan apa yang dikatakan oleh Isaksen, Dorval, \& Treffinger (2011, p.16), 'CPS not merely problem solving. The creative aspect to CPS means the focus is on facing new challenges as opportunities, dealing with unknown or ambiguous situations and productively managing the tension caused by gaps between your vision of future reality and actual current reality'. Senada dengan pernyataan tersebut tersebut, Helie \& Sun (2008, p.13) juga mengatakan bahwa, 'This approach to problem solving is typically inefficient when the problem is too complex, ill-understood, or ambiguous. In such a case, a 'creative' approach to problem solving might be more appropriate'. Creative problem solving ini sangat perlu ditumbuhkembangkan pada diri pribadi siswa, tak terkecuali siswa-siswa SMK, dimana kreativitas sangat mereka dibutuhkan dalam persaingan dunia kerja.

Posisi penting pemecahan masalah dalam pembelajaran matematika mengharuskan guru untuk menyediakan kesempatan bagi siswa untuk memecahkan masalah (Lahinda \& Jailani, 2015, p.150). Namun faktanya hal tersebut belum seutuhnya terwujud dalam pembelajaran matematika di Indonesia. Berdasarkan hasil pra survei melalui wawancara terhadap guru matematika SMK Muhammadiyah 1 Yogyakarta diperoleh beberapa argumen guru matematika terhadap kemampuan siswa dalam menyelesaikan masalah non rutin, selama pembelajaran matematika. Pertama, guru menilai secara umum kemampuan penyelesaian masalah siswa kelas XI pada pembelajaran matematika sudah baik, tetapi pada materi-materi tertentu, mereka sulit memahami materi pelajaran, dan sulit mengaplikasikan pada masalah sehari-hari. Salah satunya adalah materi vektor. Apa yang disampaikan beliau, seolah membenarkan fakta yang terjadi. Jika dilihat dari kemampuan daya serap siswa materi vektor pada UN 2013 yang dikeluarkan oleh Balitbang Depdiknas (2013).

Daya serap siswa kelas XII SMK Muhammadiyah 1 Yogyakarta pada materi vektor masih kurang. Data statistik ini juga didukung oleh dokumen akademik yang dimiliki oleh guru matematika kelas XI SMK Muhammadiyah 1 Yogyakarta, dimana sekitar 32 dari 36 siswa kelas XI tidak tuntas KKM materi vektor yang ditetapkan oleh guru matematika yaitu 70 . Artinya, memang ada masalah dengan pemahaman siswa tentang konsep vektor yang berimbas pada rendahnya prestasi belajar matematika pada materi tersebut. Padahal, aplikasi konsep vektor sangat diperlukan dalam mata pelajaran lain di SMK teknologi, kesehatan, dan pertanian.

Kedua, berdasarkan penuturan guru matematika kelas XI Muhammadiyah 1 Yogyakarta, diperoleh keterangan bahwa rata-rata siswa di SMK Muhammadiyah 1 Yogyakarta selama proses pembelajaran berlangsung ingin serba instan. Sehingga, rata-rata siswa bersikap mengacuhkan guru ketika menjelaskan penyelesaian dengan urutan langkah yang benar.

Pada kesempatan lain, hasil wawancara non formal yang dilakukan peneliti dengan empat orang siswa kelas XI SMK Muhammadiyah 1 Yogyakarta, mereka menuturkan bahwa mereka kesulitan memahami materi vektor dikarenakan faktor waktu yang relatif singkat untuk mempelajari vektor. Selain itu, vektor merupakan bab terakhir di semester genap dan juga kurang konsentrasi karena jam pelajaran matematika dilaksanakan pada siang hari. Apa yang disampaikan keempat siswa tersebut mengindikasikan bahwa faktor kesulitan belajar siswa terdiri atas faktor fisiologis, sosial, emosional, intelektual, dan pedagogis yang mana dikerucutkan pada dua faktor yakni faktor luar dan faktor dalam diri siswa. Namun, faktor pedagogis sangat berpengaruh dan mudah terlihat jika siswa 
mengalami kesulitan menyelesaikan masalah matematika. Hal tersebut disebabkan faktor pedagogis berkaitan erat dengan kesiapan siswa belajar matematika serta kematangan siswa menguasai kompetensi matematika.

Fakta lain yang diperoleh peneliti ketika berada di SMK Muhammadiyah 1 Yogyakarta adalah minimnya perangkat pembelajaran berupa LKS yang dipakai guru matematika selama proses KBM berlangsung. Hal itu pun dibenarkan oleh guru matematika SMK Muhammadiyah 1 Yogyakarta yang mengatakan bahwa LKS yang digunakan hanya 1 judul. Selain LKS, perangkat pembelajaran berupa RPP juga kurang sesuai dengan kaidah penyusunan RPP yang sesuai denganPermendiknasNomor 41 Tahun 2007 tentang Standar Proses yang disempurnakan melalui Permendikbud Nomor 81A Tahun 2013 tentang implementasi kurikulum, yang antara lain mengatur tentang perencanaan proses pembelajaran yang mensyaratkan bagi pendidik pada satuan pendidikan untuk mengembangkan Rencana Pelaksanaan Pembelajaran (RPP).

Berdasarkan paparan fenomena tersebut, penelitian ini dilaksanakan untuk mengembangkan perangkat pembelajaran matematika berupa Rencana Pelaksanaan Pembelajaran (RPP), Lembar Kegiatan Siswa (LKS), dan Tes Prestasi Belajar (TPB) melalui pendekatan Creative Problem Solving (CPS) pada materi vektor kelas XI SMK Teknokestan sehingga menghasilkan perangkat yang valid, praktis, dan efektif, tes prestasi belajar siswa (TPB) yang valid dan praktis.

\section{METODE}

Jenis penelitian ini adalah penelitian pengembangan (research \& development). Model pengembangan yang digunakan adalah model pengembangan 4D yang terdiri atas empat tahapan yaitu define, design, development, dan dissemination (Thiagarajan, Semmel \& Semmel, 1974, p.6). Penelitian ini dilaksanakan di SMK Muhammadiyah 1 Yogyakarta dari bulan Juni sampai Agustus 2014.

Subjek pada uji coba terbatas adalah 12 orang siswa SMK Muhammadiyah 1 Yogyakarta, yang terdiri atas 6 siswa kelas XI TKJ dan 6 siswa kelas XI MM. Subjek pada uji coba lapangan adalah 32 orang siswa kelas XI TKJ dan 28 orang siswa kelas XI MM serta 2 orang guru matematika SMK Muhammadiyah 1 Yogyakarta.

Prosedur pengembangan yang dilakukan peneliti meliputi proses define, design, develop, dan dissemination. Tahap pertama adalah define (pendefinisian), tujuan tahap ini adalah menentukan dan mendefinisikan syarat-syarat pembelajaran. Pada tahap ini dilakukan beberapa hal yaitu analisis awal akhir, analisis karakteristik siswa, analisis konsep, analisis tugas, dan perumusan tujuan pembelajaran.

Tahap kedua adalah tahap perancangan (design). Tujuan tahap ini adalah untuk menyiapkan prototipe perangkat pembelajaran dan alat evaluasinya. Kegiatan utama yang dilakukan pada tahap ini adalah mengkonstruksi tes menggunakan acuan kriteria, pemilihan media, pemilihan format, dan desain awal. Produk yang didesain adalah perangkat pembelajaran vektor SMK Teknokestan dengan pendekatan Creative Problem Solving (CPS) Perangkat pembelajaran yang dikembangkan adalah RPP, LKS, dan TPB.

Tahap ketiga adalah tahap pengembangan (develop). Tujuan tahap ini adalah untuk menghasilkan perangkat pembelajaran yang valid, praktis, dan efektif. Pada tahap ini dilakukan proses validasi ahli, uji coba terbatas, dan uji coba lapangan. Proses validasi dilakukan oleh satu ahli yang memvalidasi lembar validasi ahli, dua ahli yang memvalidasi produk yang dikembangkan, dan satu ahli yang memvalidasi instrumen. Uji coba terbatas dilakukan untuk menilai keterbacaan dari LKS, dan TPB yang akan digunakan dalam uji coba lapangan. Uji coba terbatas dilakukan dengan menggunakan panduan keterbacaan yang diisi oleh siswa. Setelah proses validasi dan uji coba terbatas dilakukan, selanjutnya adalah proses uji coba lapangan. Uji coba lapangan dilaksanakan untuk mengetahui bagaimana kepraktisan dan keefektifan perangkat pembelajaran.

Tahap keempat adalah diseminasi (dissemination). Tahap desiminasi pada penelitian ini dipublikasikan pada guru matematika pada sekolah yang diteliti.

Data hasil penelitian terbagi menjadi dua yaitu data kuantitatif dan data kualitatif. Data kuantitatif diperoleh dari hasil tes prestasi belajar siswa, sedangkan data kualitatif diperoleh dari hasil pengisian lembar validasi, angket (lembar penilaian guru dan lembar penilaian siswa) dan lembar observasi keterlaksanaan pembelajaran. Data kualitatif berupa hasil pengisian lembar validasi dan lembar penilaian tersebut diklasifikasikan menjadi 5 kategori pilihan. Instrumen untuk membuktikan kevalidan perangkat pembelajaran terdiri atas lembar validasi silabus, lembar validasi RPP, lembar validasi 
LKS, dan lembar validasi TPB. Lembar validasi digunakan untuk membuktikan kevalidan perangkat pembelajaran yang dikembangkan.

Instrumen yang digunakan untuk mengukur kepraktisan perangkat pembelajaran meliputi lembar penilaian kepraktisan oleh guru, lembar penilaian kepraktisan oleh siswa, dan lembar observasi keterlaksanaan pembelajaran. Sedangkan, instrumen yang digunakan untuk mengukur keefektifan pembelajaran adalah tes prestasi belajar siswa pada materi vektor.

Data kualitatif berupa hasil pengisian lembar validasi, lembar penilaian kepraktisan oleh guru, lembar penilaian kepraktisan oleh siswa, dan lembar observasi keterlaksanaan pembelajaran diklasifikasikan menjadi 5 kategori pilihan dengan rentang skala penilaian 5 yaitu skor 1 , skor 2 , skor 3 , skor 4 , dan skor 5 . Teknik analisis data dengan 5 kategori pilihan yaitu dengan mengelompokkan data berdasarkan kualifikasi produk yang akan dinilai. Berdasarkan data yang telah dikelompokkan kemudian dilakukan perhitungan untuk memperoleh nilai rata-rata. Untuk menghitung rata-rata menggunakan acuan sebagai berikut:

$$
\bar{x}=\frac{\Sigma x}{n}
$$

Keterangan:

$\bar{x}=$ skor rata-rata

$\Sigma x=$ total skor jawaban

$\mathrm{N}$ = banyak evaluator

Skor rata-rata yang diperoleh kemudian dimasukkan kedalam kategori kualitatif seperti disajikan pada Tabel 1 yang diadaptasi dari Azwar (2002, p.163).

Tabel 1. Kriteria Konversi Data Kuantitatif ke Data Kualitatif

\begin{tabular}{cc}
\hline Rentang Skor Kuantitatif & $\begin{array}{c}\text { Kriteria } \\
\text { Kualitatif }\end{array}$ \\
\hline$\overline{\mathrm{x}}>\mathrm{M}_{\mathrm{i}}+1,5 \mathrm{SB}_{\mathrm{i}}$ & Sangat Baik \\
$\mathrm{M}_{\mathrm{i}}+0,5 \mathrm{SB}_{\mathrm{i}}<\overline{\mathrm{x}} \leq \mathrm{M}_{\mathrm{i}}+1,5 \mathrm{SB}_{\mathrm{i}}$ & Baik \\
$\mathrm{M}_{\mathrm{i}}-0,5 \mathrm{SB}_{\mathrm{i}}<\overline{\mathrm{x}} \leq \mathrm{M}_{\mathrm{i}}+0,5 \mathrm{SB}_{\mathrm{i}}$ & Cukup Baik \\
$\mathrm{M}_{\mathrm{i}}-1,5 \mathrm{SB}_{\mathrm{i}}<\overline{\mathrm{x}} \leq \mathrm{M}_{\mathrm{i}}-0,5 \mathrm{SB}_{\mathrm{i}}$ & Kurang Baik \\
$\overline{\mathrm{x}} \leq \mathrm{M}_{\mathrm{i}}-1,5 \mathrm{SB}_{\mathrm{i}}$ & Sangat Kurang \\
\hline
\end{tabular}

Keterangan:

$\bar{x}=$ skor rata-rata

$\mathrm{M}=$ Rata-rata skor ideal

$=\frac{1}{2}($ skor maksimum + skor minimum $)$

$\mathrm{S}$ = Simpangan baku ideal $=\frac{1}{6}($ skor maksimum - skor minimum $)$

Perangkat pembelajaran dikatakan valid untuk digunakan dalam uji coba jika skor kevalidan tiap perangkat pembelajaran memiliki kategori minimal valid. Dengan demikian, hasil analisis data yang tidak memenuhi kategori minimal valid dalam penelitian ini akan dijadikan bahan pertimbangan untuk melakukan revisi perangkat pembelajaran sebelum diujicobakan.

Perangkat pembelajaran dikatakan praktis jika skor tiap perangkat pembelajaran mempunyai kategori minimal praktis, serta persentase keterlaksanaan pembelajaran mencapai $80 \%$. Perangkat pembelajaran dikatakan efektif jika 70\% dari jumlah siswa memenuhi kriteria ketuntasan minimal.

\section{HASIL DAN PEMBAHASAN}

Hasil pengembangan berupa perangkat pembelajaran vektor menggunakan pendekatan Creative Problem Solving (CPS) untuk siswa SMK Kelas XI Teknokestan meliputi silabus, RPP dan LKS yang valid, praktis, dan efektif, serta TPB yang valid praktis dan reliabel. Perangkat pembelajaran yang dikembangkan terdiri materi vektor pada dimensi dua dan vektor pada dimensi tiga.

Sebelum mengembangkan perangkat pembelajaran, terlebih dahulu dilakukan tahap pendefinisian untuk menentukan tujuan dan permasalahan sebagai acuan dalam penyusunan perangkat pembelajaran. Hal-hal yang dilakukan pada tahap ini adalah sebagai berikut:

Analisis awal-akhir

Analisis ini bertujuan untuk mengidentifikasi masalah dan fakta yang dijadikan dasar dalam pengembangan perangkat pembelajaran vektor SMK. Beberapa hal yang diidentifikasi dalam analisis awal-akhir diantaranya Permendiknas Nomor 23 Tahun 2006 tentang Standar Kompetensi Lulusan yang mengatakan bahwa pencapaian standar kompetensi lulusan siswa bergantung pada proses pembelajaran yang ditempuh siswa baik dalam pendidikan formal maupun informal. Proses pembelajaran yang terjadi haruslah berpusat pada siswa dan guru sebagai fasilitator serta pemberian bantuan (scaffolding) ketika siswa mengalami kesulitan dan kebingungan. Kenyataan yang terjadi saat ini adalah proses pembelajaran didominasi oleh guru dan siswa hanya mendengar dan mencatat penjelasan dari guru. Hal ini mengakibatkan suasana pembelajaran cenderung monoton dan tidak mendukung siswa untuk terlibat secara 


\section{Jurnal Riset Pendidikan Matematika, 3 (1), Mei 2016 - 71}

Muh. Fajaruddin Atsnan

aktif sehingga pengetahuan yang diperoleh siswa tidak bermakna.

Hal lain yang ditemukan adalah kesulitan siswa dalam memahami materi vektor yang terlihat dari hasil laporan ujian nasional yang dikeluarkan oleh Balitbang Kemdikbud yang menyatakan bahwa masih banyak siswa yang memiliki daya serap di bawah rata-rata pada materi vektor. Sebagai contoh, laporan tentang hasil ujian nasional di sekolah yang akan dijadikan tempat uji coba yaitu SMK Muhammadiyah 1 Yogyakarta, daya serap siswa terhadap materi vektor mengalami penurunan dari tahun $2011 \mathrm{ke}$ tahun 2012, dan tahun 2012 ke tahun 2013.

Sebelum mengembangkan produk, diadakan pra survei pada tiga sekolah yaitu SMK Muhammadiyah 1 Yogyakarta, SMK Muhammadiyah 2 Yogyakarta, dan SMK Muhammadiyah 3 Yogyakarta. Kegiatan dalam pra survei adalah observasi lingkungan sekolah, perangkat pembelajaran yang digunakan guru dan proses pembelajaran serta berdiskusi dengan guru mitra. Hasil dari pra survei di SMK Muhammadiyah 1 Yogyakarta diantaranya adalah perangkat pembelajaran yang digunakan guru selama ini kurang menarik dan tidak variatif, hanya satu LKS yang digunakan sebagai sumber belajar, materi vektor biasanya diajarkan sekilas saja, dengan alasan waktu yang mepet dan mendekati ujian kenaikan kelas. Sedangkan, hasil pra survei di SMK Muhammadiyah 2 Yogyakarta, guru matematika mengatakan bahwa LKS masih menjadi sumber belajar utama, dengan harga yang terjangkau dan praktis, tetapi hanya satu LKS yang digunakan guru dan siswa. Proses pembelajaran matematika di SMK Muhammadiyah 2 Yogyakarta beralur dari guru menjelaskan sedikit, kemudian siswa mengerjakan soalsoal di LKS, menunggu sampai bel akan berbunyi tanda ganti jam pelajaran, kemudian dibahas bersama apa yang sudah dikerjakan siswa. Kondisi berbeda peneliti temui saat pra survei di SMK Muhammadiyah 3 Yogyakarta, dimana sumber belajar yang digunakan guru tidak hanya LKS, tetapi ada modul yang dibuat guru. Meskipun pada prakteknya, ketika pembelajaran berlangsung, juga bersumber dari LKS yang sama dengan LKS di SMK Muhammadiyah 1 Yogyakarta dan SMK Muhammadiyah 2 Yogyakarta. Berdasarkan data hasil pra survei, maka peneliti menyimpulkan bahwa: pertama, sumber belajar matematika -pada ketiga sekolah tersebut masih minim. Kedua, dalam proses pembelajaran guru masih mendominasi, serta siswa kurang aktif selama pembelajaran berlangsung. Ketiga, pembelajaran materi vektor tidak sinkron antara materi ajar dengan alokasi waktu, sehingga memunculkan dugaan bahwa daya serap siswa pada materi vektor terutama di SMK Muhammadiyah 1 Yogyakarta masih rendah.

\section{Analisis karakteristik siswa}

Analisis dilakukan untuk mengetahui karakteristik siswa. Hal ini penting dilakukan karena setiap siswa memiliki karakter, watak, yang unik dan berbeda satu dengan lainnya. Hasil analisis ini diperoleh berdasarkan informasi dari guru matematika dan guru BK di SMK Muhammadiyah 1 Yogyakarta.

Hasil analisis karakteristik siswa pada SMK Muhammadiyah 1 Yogyakarta adalah siswa memiliki kemampuan akademik yang beragam yang terdiri atas tiga kelompok yaitu kelompok atas, kelompok tinggi, kelompok sedang dan kelompok rendah dan mereka memiliki latar belakang ekonomi dan sosial yang beragam. Dari hasil dialog dengan guru matematika kelas XI, Bapak Joko Supriyanto dan guru BK Ibu Suparmi, diperoleh keterangan bahwa keadaan ekonomi orang tua siswa ratarata cukup.

Siswa berada pada rentang usia 15-17 tahun yang berada pada tahap remaja. Tahap remaja merupakan tahap transisi dimana siswa mengalami perubahan fisik dan psikis yang lumayan banyak sehingga perlu mendapat perhatian khusus dari guru dan orang tua agar perkembangan mereka berjalan dengan baik.

Materi vektor belum pernah dipelajari siswa pada jenjang sebelumnya, tetapi ada beberapa materi yang dapat dijadikan apersepsi guru untuk mengenalkan vektor, misalnya materi tentang persamaan garis lurus dan gradien yang sudah dipelajari di SMP. Namun, guru matematika berpendapat bahwa siswa sudah banyak yang lupa tentang materi yang dipelajari di SMP. Hal ini menunjukkan bahwa pemahaman mereka tidak bersifat tahan lama.

\section{Analisis Konsep}

Analisis materi dilakukan dengan cara mengidentifikasi materi utama yang perlu diajarkan, mengumpulkan dan memilih materi yang relevan, dan menyusunnya kembali secara sistematis. Adapun desain dari masing-masing produk perangkat pembelajaran yang dikembangkan dijelaskan pada uraian berikut ini.

$$
\text { Rencana Pelaksanaan Pembelajaran }
$$
(RPP) dikembangkan dengan mengacu pada 
Permendiknas Nomor 42 Tahun 2007 tentang Standar Proses, memuat komponen standar kompetensi, kompetensi dasar, indikator pencapaian kompetensi, tujuan pembelajaran, materi ajar, alokasi waktu, metode pembelajaran, kegiatan pembelajaran, alat dan sumber belajar serta penilaian hasil belajar. Rencana pelaksanaan pembelajaran yang dikembangkan pada materi vektor mencakup satu standar kompetensi (SK) yang masing-masingnya terdiri atas dua kompetensi dasar (KD). Menurut Badan Standar Nasional Pendidikan (BSNP), satu RPP dirancang untuk satu kompetensi dasar. RPP yang disusun untuk draft awal sebanyak dua RPP untuk enam pertemuan, dimana masing-masing RPP untuk tiga pertemuan dengan rincian tiga pertemuan untuk materi vektor pada dimensi dua $\left(\mathrm{R}_{2}\right)$ dan tiga pertemuan untuk materi vektor pada dimensi tiga $\left(\mathrm{R}_{3}\right)$.

Lembar kegiatan siswa yang dikembangkan berpedoman pada konsep dan prinsip materi vektor SMK Teknokestan yang ada dalam buku pelajaran SMK Teknokestan yang diterbitkan oleh pusat perbukuan Depdiknas. LKS dibuat untuk satu standar kompetensi (SK) yang masing-masingnya terdiri atas dua kompetensi dasar (KD). LKS yang dirancang untuk produk awal adalah sebanyak 5 (lima) LKS dengan rincian 3 (tiga) LKS untuk materi vektor pada dimensi dua $\left(\mathrm{R}_{2}\right)$ dan 2 (dua) LKS untuk materi vektor pada dimensi tiga $\left(\mathrm{R}_{3}\right)$. Pengembangan LKS menyesuaikan dengan skema materi vektor. Pada LKS terdapat kegiatan yang dikerjakan secara berkelompok, kegiatan tersebut dirancang berdasarkan 5 (lima) langkah pada pendekatan Creative Problem Solving. Kegiatan dalam LKS memberikan siswa kesempatan untuk menemukan sendiri konsep yang akan dipelajarinya dan akhirnya menemukan penyelesaian (solusi) terbaik untuk menyelesaikan masalah yang ditemui.

Tes Prestasi Belajar (TPB) yang dikembangkan berdasarkan pada perumusan indikator dan tujuan pembelajaran. TPB yang dikembangkan adalah pada materi vektor SMK Teknokestan yang terdiri atas satu standar kompetensi (SK). Pada penelitian ini akan dikembangkan dua TPB, satu untuk materi vektor pada dimensi dua $\left(\mathrm{R}_{2}\right)$ dan satu lagi untuk materi vektor pada dimensi tiga $\left(\mathrm{R}_{3}\right)$. TPB pada draf 1 merupakan produk awal dari pengembangan dengan bentuk soal uraian yang terdiri atas 7 soal untuk materi vektor pada dimensi dua dan 3 soal untuk materi vektor pada dimensi tiga.
Produk awal ini berupa perangkat pembelajaran yang telah dikembangkan yang kemudian akan divalidasi oleh beberapa ahli. Produk akan direvisi sesuai dengan saran-saran dari validator agar memenuhi kriteria kevalidan. Validasi ini harus dilakukan sebelum peneliti melaksanakan uji coba produk.

Penilaian kevalidan perangkat pembelajaran dilakukan oleh dua dosen pendidikan matematika. Hasil validasi disajikan pada Tabel 2.

Tabel 2. Skor Validasi Perangkat Pembelajaran

\begin{tabular}{cccc}
\hline \multirow{2}{*}{ Validator } & \multicolumn{3}{c}{$\begin{array}{c}\text { Skor Perangkat Pembelajaran } \\
\text { yang Divalidasi }\end{array}$} \\
\cline { 2 - 4 } & RPP & LKS & TPB \\
\hline 1 & 105 & 125 & 70 \\
2 & 92 & 95 & 58 \\
Skor Total & 197 & 220 & 128 \\
Rata-rata & 98,5 & 110 & 64 \\
\hline
\end{tabular}

Dari Tabel 2 dapat dilihat bahwa perangkat pembelajaran yang dikembangkan valid.

Kepraktisan dari perangkat pembelajaran yang dikembangkan diketahui dari analisis hasil lembar penilaian kepraktisan oleh guru, lembar penilaian kepraktisan oleh siswa, dan hasil observasi keterlaksanaan pembelajaran. Data lembar penilaian kepraktisan perangkat pembelajaran oleh guru adalah data kuantitatif yang dikonversi menjadi data kualitatif untuk menentukan kriteria kepraktisan perangkat pembelajaran (silabus, RPP, LKS dan TPB). Perangkat pembelajaran dikatakan praktis jika skor rata-rata perangkat pembelajaran memenuhi kategori minimal praktis, yaitu $22,5<\bar{x} \leq 27,5$ untuk RPP, $22,5<\bar{x} \leq 27,5$ untuk LKS, dan 16,67 < $\bar{x} \leq 20$ untuk TPB. Berikut ini hasil analisis penilaian perangkat pembelajaran oleh guru disajikan pada Tabel 3.

Tabel 3.Penilaian Kepraktisan Perangkat Pembelajaran oleh Guru

\begin{tabular}{cccc}
\hline \multirow{2}{*}{ Guru } & \multicolumn{3}{c}{ Skor Produk } \\
\cline { 2 - 4 } & RPP & LKS & TPB \\
\hline 1 & 35 & 32 & 24 \\
2 & 32 & 30 & 23 \\
Skor & 67 & 62 & 47 \\
Total & & & \\
Rata-rata & 33,5 & 31 & 23,5 \\
Kriteria & $\begin{array}{c}\text { Sangat } \\
\text { praktis }\end{array}$ & $\begin{array}{c}\text { Sangat } \\
\text { praktis }\end{array}$ & $\begin{array}{c}\text { Sangat } \\
\text { praktis }\end{array}$ \\
\hline
\end{tabular}

Hasil analisis kepraktisan untuk setiap perangkat pembelajaran dari Tabel 3 , menunjukkan bahwa secara keseluruhan dapat dikatakan 
bahwa perangkat pembelajaran yang dikembangkan mencapai kategori sangat praktis.

Data Lembar penilaian kepraktisan oleh siswaadalah data kuantitatif yang dikonversi menjadi data kualitatif untuk menentukan kategori kepraktisan perangkat pembelajaran (LKS). Perangkat pembelajaran dikatakan praktis jika skor rata-rata perangkat pembelajaran memenuhi kategori minimal praktis, $26,67<\bar{x} \leq 32$ untuk LKS dan $20<\bar{x} \leq 24$ untuk TPB. Hasil analisis penilaian kepraktisan LKS oleh siswa disajikan pada Tabel 4.

Tabel 4. Penilaian Kepraktisan LKS oleh Siswa

\begin{tabular}{ccccc}
\hline No & Siswa & $\begin{array}{c}\text { Jumlah } \\
\text { Siswa }\end{array}$ & \multicolumn{2}{c}{$\begin{array}{c}\text { Skor Penilaian } \\
\text { Perangkat } \\
\text { pembelajaran }\end{array}$} \\
\cline { 3 - 5 } & & 32 & 1.018 & 718 \\
\hline 1 & Kelas XI & & TPB \\
\hline & TKJ & & & \\
2 & Kelas XI & 28 & 897 & 640 \\
& MM & & 1915 & 1358 \\
& Skor Total & & 31,92 & 22,63 \\
& Rata-rata & & Praktis & Praktis \\
\hline
\end{tabular}

Hasil analisis kepraktisan untuk setiap perangkat pembelajaran dari Tabel 4, menunjukkan bahwa secara keseluruhan dapat dikatakan bahwa perangkat pembelajaran yang dikembangkan mencapai kategori praktis.

Data observasi keterlaksanaan pembelajaran diperoleh dari observasi keterlaksanaan pembelajaran di kelas yang dilakukan oleh guru pada setiap pertemuan dengan menggunakan perangkat pembelajaran yang dikembangkan. Observasi dilakukan oleh observer dengan menggunakan lembar observasi yang telah dibuat oleh peneliti. Hasil observasi keterlaksanaan pembelajaran disajikan pada Tabel 5.

Tabel 5. Hasil Observasi

KeterlaksanaanPembelajaran

\begin{tabular}{lccccc}
\hline \multirow{2}{*}{ No } & \multirow{2}{*}{ Siswa } & \multicolumn{4}{c}{ Skor pada Pertemuan ke- } \\
\cline { 3 - 6 } & & $\mathbf{1}$ & $\mathbf{2}$ & $\mathbf{3}$ & $\mathbf{4}$ \\
\hline 1 & Kelas XI TKJ & 20 & 20 & 20 & 20 \\
2 & Kelas XI MM & 20 & 20 & 21 & 20 \\
Jumlah Skor & 40 & 40 & 61 & 62 \\
Persentase (\%) & 83,3 & 84,7 & 84, & 86,1 \\
\hline
\end{tabular}

Berdasarkan Tabel 5, dapat diketahui bahwa persentase keterlaksanaan proses pembelajaran pada setiap pertemuan mencapai $80 \%$. Secara keseluruhan dapat disimpulkan bahwa perangkat pembelajaran mencapai kriteria praktis. Dengan demikian dapat disimpulkan bahwa perangkat pembelajaran yang dikembangkan telah memenuhi kriteria kepraktisan jika ditinjau dari penilaian kepraktisan oleh guru, penilaian kepraktisan oleh siswa, dan observasi keterlaksanaan pembelajaran.

Keefektifan perangkat pembelajaran yang dikembangkan ditinjau dari aspek pretasi belajar siswa dan pengembangan pengetahuan karakter siswa. Aspek prestasi belajar siswa diukur berdasarkan data hasil TPB. pencapaian ketuntasan belajar siswa secara individual dan presentase ketuntasan siswa secara klasikal yaitu sebanyak $70 \%$ dari jumlah siswa dalam satu kelas telah memenuhi nilai kriteria ketuntasan minimal $(\mathrm{KKM})$. Berdasarkan data hasil tes prestasi belajar siswa diperoleh analisis seperti pada Tabel 6.

Tabel 6. Data Tes Prestasi Belajar

\begin{tabular}{ccccc}
\hline No & Siswa & $\begin{array}{c}\text { Nilai } \\
\text { Rata- } \\
\text { rata }\end{array}$ & $\begin{array}{c}\text { Jumlah } \\
\text { Siswa }\end{array}$ & $\begin{array}{c}\text { Persentase } \\
\text { Ketuntasan }\end{array}$ \\
\hline 1 & $\begin{array}{c}\text { Kelas XI } \\
\text { TKJ } \\
\text { Kelas XI } \\
\text { MM }\end{array}$ & 77,81 & 32 & $81,25 \%$ \\
\hline
\end{tabular}

Persentase ketuntasan untuk kelas TKJ adalah $81,25 \%$ sedangkan untuk kelas MM sebesar $71,42 \%$. Hasil analisis data tersebut menunjukkan bahwa banyak siswa yang mencapai KKM pada setiap kelas lebih dari 70\%. Sehingga dapat disimpulkan bahwa perangkat pembelajaran yang dikembangkan telah mencapai kriteria efektif.

Berdasarkan tahap pendefinisian, penelitian ini mengembangkan perangkat pembelajaran vektor SMK dengan pendekatan Creative Problem Solving yang dibatasi untuk kelas XI SMK Teknokestan dengan satu standar kompetensi (SK) yang terdiri atas dua kompetensi dasar (KD). Kelayakan dari produk akhir berupa perangkat pembelajaran vektor dengan pendekatan Creative Problem Solving, terdiri atas RPP, LKS, dan TPB, akan ditinjau dari tiga hal yaitu kevalidan, kepraktisan, dan keefektifan.

Berdasarkan hasil validasi yang dilakukan oleh ahli yang berkompeten maka diperoleh komentar dan masukan agar produk yang dikembangkan mencapai kriterian valid. Setelah melakukan berbagai perbaikan, maka perangkat pembelajaran yang dihasilkan yang terdiri atas RPP, LKS, dan TPB, dinyatakan telah mencapai kriteria sangat valid. Hal ini didukung oleh penyusunan RPP yang mengacu pada prinsipprinsip dan komponen yang ada Permendikbud 
Nomor 65 Tahun 2013 tentang Standar Proses. Penyusunan LKS mengacu pada tahapan penyusunan LKS menurut Depdiknas (2008, p.23-24). Penyusunan TPB disesuaikan dengan prinsipprinsip yang yang tercantum dalam Permendikbud Nomor 66 Tahun 2013 tentang Standar Penilaian dan teori yang dikemukakan Gronlund, et al. (2009, p.139-169). Semua produk yang dihasilkan memuat komponen tentang sumber belajar di lingkungan sekitar. Sehingga berdasarkan hasil validasi oleh beberapa ahli, perangkat pembelajaran yang dihasilkan sudah layak digunakan setelah dilakukan revisi terlebih dahulu.

Berdasarkan hasil uji coba terbatas dan uji coba lapangan dapat diketahui bahwa perangkat pembelajaran yang dihasilkan telah mencapai kriteria sangat praktis. Kepraktisan diukur dari penilaian kepraktisan guru dan siswa serta observasi keterlaksanaan pembelajaran. Keterlaksanaan pembelajaran mencapai lebih dari $80 \%$ yang menunjukkan bahwa dengan perangkat pembelajaran yang dihasilkan, kegiatan pembelajaran yang memanfaatkan sumber belajar di lingkungan sekitar dapat terlaksana dengan baik. Penilaian kepraktisan dari guru dan siswa menunjukkan bahwa perangkat pembelajaran yang dihasilkan mencapai kriteria sangat praktis. Kriteria praktis dapat dicapai karena produk yang dikembangkan sesuai dengan komponen-komponen dan kemanfaatan dari sumber belajar di lingkungan sekitar yang dapat mempermudah proses pembelajaran. Hal tersebut sesuai dengan pendapat beberapa ahli yaitu AECT (1977, p.8), Davies et. al (2008, p.5), Komalasari (2010, p.114), dan Drews \& Hansen (2007, p.20-21).

Berdasarkan hasil uji coba lapangan dapat diketahui bahwa perangkat pembelajaran yang dihasilkan telah mencapai kriteria efektif. Keefektifan diukur dari ketuntasan siswa dalam mengerjakan TPB. Hasil dari analisis TPB menunjukkan bahwa persentase ketuntasan siswa pada setiap sekolah yang diteliti adalah lebih dari $70 \%$. Berdasarkan hasil tersebut dapat disimpulkan bahwa perangkat pembelajaran dapat dikatakan efektif. Prestasi belajar bisa meningkat jika siswa bisa lebih mudah memahami suatu materi.

Berdasarkan deskripsi kajian kevalidan, kepraktisan, dan keefektifan, dapat disimpulkan bahwa produk perangkat pembelajaran vektor SMK dengan pendekatan Creative Problem Solving telah teruji kevalidan, kepraktisan, dan keefektifannya. Sehingga pada akhirnya produk perangkat pembelajaran vektor SMK Teknokes- tan yang terdiri atas RPP, LKS, dan TPB layak digunakan dalam kegiatan pembelajaran matematika.

Beberapa keterbatasan yang terdapat pada penelitian ini antara lain model pengembangan perangkat pembelajaran yang digunakan sesuai dengan metode penelitian adalah model $4 \mathrm{D}$ yang dikembangkan oleh Thiagarajan, Dorothy S. Semmel, dan Melvyn I. Semmel meliputi define, design, develop, dan disseminate. Namun, pada penelitian ini hanya dilaksanakan pada tiga tahap yaitu define, design, dan develop. Selain itu, pada penelitian ini, setelah tahap revisi akhir tidak dilaksanakan lagi uji coba akhir. Draft setelah revisi akhir tersebut langsung menjadi produk akhir perangkat pembelajaran.

\section{SIMPULAN DAN SARAN}

\section{Simpulan}

Simpulan dari penelitian ini adalah hasil pengembangan adalah produk berupa perangkat pembelajaran matematika materi vektor SMK Teknokestan dengan pendekatan Creative Problem Solving, yang meliputi Rencana Pelaksanaan Pembelajaran (RPP), Lembar Kegiatan Siswa (LKS) yang valid, praktis, dan efektif, dan Tes Prestasi Belajar (TPB) yang valid, praktis, dan reliabeluntuk digunakan. Perangkat pembelajaran matematika materi vektor SMK Teknokestan dengan pendekatan Creative Problem Solving yang dihasilkan terdiri atas RPP, LKS, dan TPB setelah melalui tahap validasi, disimpulkan bahwa perangkat pembelajaran memenuhi kriteria valid, setelah melalui tahap akhir uji coba lapangan, disimpulkan bahwa perangkat pembelajaran dinyatakan praktis, serta perangkat pembelajaran berupa RPP dan LKS yang dihasilkan efektif digunakan. Selain itu dihasilkan TPB yang reliabel. Secara empiris soal diujikan kembali dengan metode paralel untuk mengetahui reliabilitasnya. Data diambil dari siswa yang menjadi subjek uji coba. Dari analisis data diperoleh koefisien korelasi sebesar 0,5002 dan SEM (Standard Error Measurement) sebesar 14,95 .

\section{Saran}

Hal-hal yang dapat disarankan setelah melakukan penelitian ini adalah perangkat pembelajaran matematika materi vektor SMK Teknokestan dengan pendekatan Creative Problem Solving yang dihasilkan terdiri atas RPP dan LKS, yang dihasilkan telah memenuhi kriteria valid, praktis dan efektif, sedangkan untuk TPB 
memenuhi kriteria valid dan praktis, sehingga layak dimanfaatkan untuk pembelajaran di kelas. Pengembangan perangkat pembelajaran matematika materi vektor SMK Teknokestan dengan pendekatan Creative Problem Solving terbatas pada materi vektor dimensi dua dan vektor pada dimensi tiga, sehingga disarankan untuk peneliti lain agar dapat mengembangkan perangkat pembelajaran matematika dengan pendekatan Creative Problem Solving pada materi yang lain.

\section{DAFTAR PUSTAKA}

AECT. (1977). The definition of educational technology. Association for Educational Communication and Technology.

Azwar, S. (2002). Tes prestasi fungsi pengembangan pengukuran prestasi belajar. Yogyakarta: Pustaka Pelajar.

Balitbang Depdiknas. (2013). Laporan Hasil Ujian Nasional Tahun Ajaran 2012/2013.

Chambers, P. (2008). Teaching mathematics. London: SAGE Publications.

Davies, et al. (2008). Evaluation and selection of learning resouces: a guide. Canada: Prince Edward Island.

Drews, D. \& Hansen, A. (2007). Using resource to suppore mathematical thinking primary and early years. Glasgow: Learning Matters.

Depdiknas. (2008). Penyusunan silabus dan rencana pelaksanaan pembelajaran (RPP) matematika SD. Dalam rangka pengembangan KTSP. Yogyakarta: PPPTK.

Gauhar, S. (2012). Mathematics is The Queen of Sciences. Tersedia: http://enu.kz/repository/repository2012/m athematics.pdf. diakses pada tanggal 3 Agustus 2013.

Gronlund, et al. (2009). Measurement and assessment in teaching.Upper Saddle River, NJ: Pearson Education, Inc.

Helie, S. \& Sun, R. (2008). Knowledge Integration in Creative Problem Solving. [Online]. Tersedia di: www.helie- $\operatorname{cog} 08$ cps. [30 Juli 2013].

Isaksen, S.G., Dorval, K.B., \& Treffinger, D.J. (2011). Creative approaches to problem solving: a framework for innovation and change. California: SAGE Publications, Inc.

Komalasari. (2013). Pembelajaran kontekstual konsep dan aplikasi. Bandung: Refika Aditama.

Lahinda, Y., \& Jailani, J. (2015). Analisis proses pemecahan masalah matematika siswa sekolah menengah pertama. Jurnal Riset Pendidikan Matematika, 2(1), 148 - 161. doi:http://dx.doi.org/10.21831/jrpm.v2i1. 7157

Mendiknas. (2005). Peraturan Nomor 19 tentang Standar Nasional Pendidikan.

Mendiknas.(2007). Permendiknas Nomor 41 tentang Standar proses. Jakarta: Depdiknas.

Mendikbud. (2013a). Peraturan Menteri Pendidikan dan Kebudayaan Nomor 65 Tahun 2013 tentang Standar Proses.

Mendikbud. (2013b). Peraturan Menteri Pendidikan dan Kebudayaan Nomor 66 Tahun 2013 tentang Standar Penilaian.

Mendikbud. (2013) Peraturan Menteri Pendidikan dan Kebudayaan Nomor 81A Tahun 2013 tentang Implementasi Kurikulum.

Steiner, G. (2009). "The Concept of Open Creativity: Collaborative Creative Problem Solving for Innovation Generation-a Systems Approach". Journal of Businessand Management. 15 (1), 5-33.

Sulistyowati, Y., \& Sugiman, S. (2014). Pengembangan perangkat pembelajaran bangun ruang di SMP dengan pendekatan creative problem solving. PYTHAGORAS: Jurnal Pendidikan Matematika, 9(2), 219232.

doi:http://dx.doi.org/10.21831/pg.v9i2.90 82

Thiagarajan, S., Semmel, D. S., dan Semmel, M. I. (1974). Instructional development for training teachers of exceptional childern. Bloomington: Indiana University.

Tileston, D. W. (2007). Teaching Strategies for Active Learning. California Corwin Press. 